\title{
The Importance of ISO 2200 in Traditional Food in Indonesia, Case in Rendang Catering
}

\author{
Filma Festivalia, Dewi Savitri, \& Mimi Engrani \\ Hotel \\ Sekolah Tinggi Pariwisata Trisakti \\ Jakarta, Indonesia \\ FFFestivalia_06@yahoo.co.id
}

\begin{abstract}
Not just a quality management system for the food industry as the important things, ISO 22000 which incorporate with Hazard Analysis Control Point (HACCP) and other preventive plans also need to be a apply soon to ensure food safety. In Indonesian cases, especially in meet food catering such as rendang has some problem such as variety of diseases and contamination of food products of animal origin. It can cause anxiety societies that exist throughout the world, which consequently affect the attitude of consumers. Therefore, consumers are becoming more curious information about the source of the products they consume. This quirosity become pressure from consumers to produsen. As we know many changes that occur in the production of food, in terms of both quality and safety. The objective of this study to determine food safety practice and procedures related to the food safety management system in Rendang. The data were obtained use survey method to 5 catering/restaurant at Bintaro Jakarta area. The result shows that not all producers following hygene requirement such as ingredient, meat process and stora.
\end{abstract}

Keywords - ISO 2200, HACCP, meat food.

\section{INTRODUCTION}

Rendang is one of the authentic Indonesian originated from the Minangkabau, West Sumatera one of ethnic group of Indonesia, food originating from West Sumatra and was originally a typical food which only consumed by local people with a distinctive flavor and accepted by the community and are influenced by people's eating habits and integrated within the system of social culture of various ethnic groups. The preferred food for flavor, texture and aroma to his taste that is not easily changed, even though members of the relevant ethnic moved to other areas.

Rendang is a one of the best dish which and is now is easly to find anywhere. Rendang is spycy meat, it is served on special occasion such as ceremonial, festive occasions such as traditional ceremonies, wedding feasts and Hari Raya (Eid alFitr).or to honour guests. Rendang today can be obtained anywhere in Indonesia, it's unique and tasty have made the food rendang this being the only food Indonesia elected in 2011 an online poll of 35,000 people by CNN International chose rendang as the number one dish of Reviews their "World's 50 Most Delicious Foods (Readers' Pick).
Rendang is made from meat as the main ingredient and cooked specifically using a range of traditional seasoning spice native to Indonesia. Which is believed to have a sense of natural, nutritious, healthy, safe, inexpensive, easy to obtain and in accordance with the tastes of society. "Rempahnya" (seasoning ingredient) is Karambia (coconut milk) and a mixture of spices typical of mashed like chili, galangal, ginger, turmeric, garlic and other spices.

These foods also having positive aspects and unique because it has antiseptic properties, a substance that has a function as a natural preservative and is also known proved to have strong antimicrobial activity, so that the meal can last for months without using preservatives.

Processing meat becomes rendang could be done for less than 1 (one) hour but to obtain good taste, the sauce is thick, tender meat and the ability to last longer then the process of cook will be done up to eight hours to completely dry gravy.. Cooking rendang involves pounding and grinding ingredients as well as slow cooking, and so is time-consuming and requires patience and If cooked properly, dry rendang can last for as long as four weeks.

Rendang contains Vitamins, nutrition, animal substances, fats and proteins. Vitamin serves to smooth metabolism, maintain endurance and immunity. Protein has a primary function as a builder substance. Fat is the second source of energy after carbohydrates and can dissolve vitamin A, D, E, and $\mathrm{K}$.

In the meat processing becoming rendang turns out has been done traditionally and falling down so many things that are not in accordance with health procedure as specified in ISO 22000 and HACCP, which is the standard International how food production to food safety a high

\section{History of rendang}

Rendang is found at the beginning of the 19th century, but Gusti Anan, a historian from the University of Andalas in Padang has alleged that rendang has begun to emerge since the 16 th century. This he inferred from the records of the 19th century literature where it is written that the land Minang people often travel to the Strait of Malacca to Singapore. The journey they went through the waterway and could take 
approximately one month. Given the absence of villages along the journey, the nomads must have been preparing some food that will hold up long time and the food was rendang. Gusti also suspect that the opening of a new village on the east coast of Sumatra to Singapore, Malacca and Malaysia by the Minang community in the 16th century also include rendang as their food for the journey it took months.

Aside from the historical record, the history of typical Padang rendang dishes can also be found in the diary of Colonel Stuers who in 1827 wrote about the culinary and literary. On the recordings often appear implicitly description culinary allegedly led to the rendang and written term food blackened and burned

Traditionally the term rendang in Minangkabau language does not refer to a certain type of dish. The verb merendang actually refers to a method of slow cooking; continuously churning the ingredients in a pot or frying pan, on a small fire, until all of the liquids evaporate and the meat is well done. ${ }^{[9]}$ Traditional Padang rendang takes hours to cook. Cooking rendang involves pounding and grinding ingredients as well as slow cooking, and so is time-consuming and requires patience. ${ }^{[10]}$ The meat pieces are slowly cooked in coconut milk and spices until almost all the liquid is gone, allowing the meat to absorb the condiments. The cooking process changes from boiling to frying as the liquid evaporates. The slow cooking process allows the meat to absorb all the spices and become tender. ${ }^{[11]}$ To cook the meat until tender with almost all the liquid evaporated requires great care, if the meat is not to be burnt or spoilt. Because of its generous use of numerous spices, rendang is known for having a complex and unique taste.

In the process of making Rendang first thing to do is Meat must be in room temperature and not frozen, then washed the meat until the blood is lost at a glance the clean of dirt, seperated the meat between the fat and to pure meat. To make the meat becomes tender we should boiled, it will certainly reduce the nutritional content/protein from the meat. The meat will then be cut into pieces with a knife and a marinade will be pulverized or use a blender so smooth As a complementary sense then used coconut milk, shredded coconut milk from coconuts is already a lot in packaging sold in supermarkets, but some very ith Restaurant menurangi sense when using it for very coconut milk for health because it contains

Cook the coconut milk turmeric leaves, kaffir lime leaves ang lemongrass. Then enter the spice paste to a boil and reduce flame. Then enter the meat is cut into pieces and stirring constantly with a flat to mature evenly. Cook beef over medium heat until thickened and somewhat dry milk and meat has become tender. Once served hot or cold according to individual taste. The most come for table if served with white rice and crackers.

Place the banana peppers, shallots, garlic, salt, and ground red pepper in a blender, and pulse until the mixture is a paste.

Place the beef tenderloin cubes in a skillet over medium heat with the pepper mixture, galangal, lemon grass, lime leaves, and turmeric. Cook the beef with the seasonings, stirring occasionally, until the meat is no longer pink inside and the meat juices have mostly evaporated, about 15 minutes.
Pour the coconut milk into the skillet, bring to a boil, reduce the heat, and simmer for about 15 minutes. Remove the pieces of beef to a bowl, and let the coconut milk continue to simmer until thickened, about 30 minutes. Return the beef to the coconut sauce, reduce the heat to low, and barely simmer the beef and sauce until the sauce turns brown and the oil has separated from the coconut milk, about $21 / 2$ hours. Stir frequently as the sauce thickens

\section{METHOD}

Qualitative research by interviewing 5 catering company in Bintaro area, the main reason is the place has many popularity and has Padang Catering/Restaurant which different segmentation, the interviewing for getting the story behind a participant's experiences. The interviewer can pursue in-depth information around the topic.

\section{RESULT}

Still found food products that do not meet quality and safety requirements. :

The meat, which we did not know from which farm, no certificate of halal, how the storage procedure, use powder to tenderize, not clean (bloody), too clean could less nutrition's hygiene or the information when expired date.

Coconut milk still use for ingredient of Rendang even actually it could be change to milk which where more healthy and less fat. Besides that Coconut milk not flushing using hot water or Coconut milk is not boiled properly

The ingredient buy from the nearest shop from their cateuse of additives, chemical contaminants, pathogen contamination, e. Aspects of meat processing heated numerous times, good taste but less nutrition. Some Rendang move from big restaurant to small restaurant if the stock still many and here are still many cases of food poisoning because most have not been reported and the cause has not been identified.

There is still a lack of knowledge, skills and responsibility of food producers about quality and food safety, especially in small industry and home industries. Lack of purchasing power for food products quality and high security level.

\section{CONCLUSION}

The ISO 22000 family of International Standards addresses food safety management.

The things to do is:

Introduce ISO 2200 and Give some training to the owner to let them know that hygiene is important thing and make customer confidence to eat the product. Low risk because the healthy food could give good impact to our body.

Give information that traditional could be go International if we could show the internationally recognized processes to your business

Give suppliers and stakeholders confidence good taste, good cook, and good standard. 


\section{REFERENCES}

Owen, Sri (1993). The Rice Book. Doubleday. ISBN 0-71122260-6.

Taylor, Jean Gelman (2003). Indonesia: Peoples and Histories. New Haven and London: Yale University Press. p. 46. ISBN 0-300-10518-5.

Lipoeto, Nur I; Agus, Zulkarnain; Oenzil, Fadil; Masrul, Mukhtar; Wattanapenpaiboon, Naiyana; Wahlqvist, Mark L (February 2001). "Contemporary Minangkabau food culture in West Sumatra, Indonesia". Asia Pacific Journal of Clinical Nutrition. Blackwell Synergy. 10 (1). doi:10.1046/j.1440-6047.2001.00201.x. PMID 11708602

Indonesia Proud: William Wongso: Duta Rendang di Dunia Kuliner Internasional
Tim Cheung (7 September 2011). "Your pick: World's 50 best foods". CNNGo. Retrieved 19 May 2015.

Urang Minang.com Inilah Rendang Minang Juara dunia itu Brissenden, Rosemary (2007). Southeast Asian Food, Classic and modern dishes from Indonesia, Malaysia, Singapore, Thailand, Laos, Cambodia and Vietnam. Periplus. p. 102. ISBN 0794604889. Retrieved 31 October 2014.

Winiati Pudji Rahayu (2000). "Aktivitas Antimikroba Bumbu Masakan Tradisional Hasil Olahan Industri Terhadap Bakteri Patogen Perusak" (PDF) (in Indonesian). Retrieved 20 September 2015.

http://beritanda.com/index.php/serbaserbi/kuliner/3312menguak-sejarah-masakan-rendang-khas-padang-yangmendunia

http://www.organisasi.org/1970/01/isi-kandungan-gizirendang-komposisi-nutrisi-bahan-makanan.html. 